\title{
Analysis on the Semantic Feature of New Acronym in Russian after the Collapse of the Soviet Union
}

\author{
Guojiang Qi \\ College of Foreign Languages \\ Heihe University \\ Heihe, Heilongjiang, China 164300
}

\begin{abstract}
The collapse of the Soviet Union has had a history of more than twenty years. In the contemporary era, the Russian society is changing sharply. The new acronyms are used more extensively in scientific language, political comment and official documents. The paper has discussed the semantic features of new Russian acronyms in recent years through the classification method and the qualitative description method. The research conclusions have theoretical value in enriching and supplementing the semantics of Russian, guiding the teaching of newspaper and periodical reading in Russian and translation practice and providing references for the lexicography.
\end{abstract}

Keywords-the collapse of the Soviet Union; new acronym; semantic feature

\section{THE MONOSEMY OF NEW ACRONYMS}

Most Russian words have many meanings. These words are called polyseme. The capacity of lexeme with many meanings is called the polysemy. The monoseme is opposite to the polyseme. In modern Russian, words with one meaning are called the monoseme. The capacity of vocabulary used for one meaning is called the monosemy of words.

Firstly, the monoseme refers to some proper nouns. Different meanings cannot appear in the words with extremely concrete meanings. So they represent the unique things.

Secondly, the monoseme often refers to the new words that haven't been used widely temporarily.

Thirdly, the monoseme refers to the words with narrow meanings. Most of them represent some things for specific purposes, so it is seldom used in the language. It has single meaning.

Fourthly, the names of terms are often monoseme. If the lexeme of standard language is used in the term, the meaning of term is independent and fixed as the only special significance.

In the contemporary era, the Russian society is witnessing dramatic changes, leading to the appearance of some new institutions and organizations. Plenty of new acronyms have appeared in the modern Russian. Most acronyms are used to represent nouns related to institutions, unit, country, social organizations, industrial and mining enterprises, plan, product

Fund project: This paper is one of the achievements of 2014 Heilongjiang province philosophy and social science research plan annual project, the Research on the New Russian Acronyms in Twenty Years after the Collapse of the Soviet Union, funded by the "Young Top-notch Talent Support Program in Scientific Research of Heihe University". and task and used in scientific language, political comment and official document (Wang Yangzheng 2008: 181). In reality, all the acronyms are monoseme. In the dictionary of new acronyms, each acronym is recorded as the independent entry and its paraphrasing provides the only interpretation.

\section{The SynONymy BetweEn NeW ACRONYMS AND The PRIMARY STRUCTURE}

Synonyms refer to the words with the same or similar meaning but different prounciations, naming things, phenomenon and behavior by different ways. They are different in meaning or rhetoric or both. (Yang Jie 2009: 56)

Each letter in the acronym represents each word in the primary structure. Each acronym is the symbolic representation of the primary structure. The acronym cannot do without the primary structure. The total dependence between the acronym and the primary structre determines synonymy exists between them:

Firstly, the new acronym appears in the text along with the primary structure. For example:

В последние годы важным фактором международной жизни в АТР становится Шанхайская организация сотрудничества (ШОС). In recent years, the Shanghai Cooperation Organization (SCO) has become important element in the international life of the Asian-Pacific region.

Secondly, the new acronym appears in the text as the second name of the primary structure. For example:

28 марта 2015 года Россия решила вступить в Азиатский банк инфраструктурных инвестиций , созданный по инициативе Китая. Об этом сообщил первый вице-премьер РФ Игорь Шувалов. Председатель КНР Си Цзиньпин поприветствовал решение России вступить в создаваемый Китаем АБИИ, заявил министр финансов Китая Лоу Цзивэй. (Igor Shuvalor, the first deputy prime minister of Russia, declares Chinese president Xi Jinping has welcomed Russia to join the Asian Infrastructure Investment Bank built under the proposition of China.)

According to the research, as a synonym of the primary structure, the new acronym can substitute the primary structure (word group) in the text, equal to a pronoun functionally. The difference is that a pronoun can substitute many nouns but an 
acronym can only substitute the primary structure (word group).

\section{FOREIGN ACRONYMS}

The collapse of the Soviet Union has brought dramatic changes for the society and the political system of Russia. The most striking characteristic on language is that various new concepts and ideological trends swarm into Russia accompanied by the western material culture and technology. The borrowing of foreign words is a common, healthy and reasonable inevitable phenomenon in the language development. The reasonable and moderate introduction of foreign words is an effective means to enrich the national language and strengthen the language expression. The introduction of foreign words has very close relationship with social culture. The degree of opening of society keeps pace with the active degree of the foreign words phenomenon.

Foreign word in the modern Russian is one of the labels of the language style in the era. The research finds acronym exists in all languages of the world, while one language introduces the acronym from another. On the structure type, the foreign acronyms can be divided into:

The first is the Russian acronym transformed by the foreign acronyms. Such as:

КАФ - стоимость и фрахт Derive from the English acronym CAF (Cost and Freight)

БНП - Национальный парижский банк Derive from the French acronym BNP (Banque Nationale de Paris)

БНЛ - Национальный банк труда Derive from the Italian acronym BNL (banca nazionalita del lavoro)

The second is the acronym with the morphological characteristics of Russian words.

БОМЖ - без определённого места жительства (А man without a fixed residence) belongs to the second variable masculine animal noun grammatically. The conjugates produced by it include Бомжиха (women without fixed residence), бомжатник (the shelter of vagrant), and Бомжовый (vagrant), Бомжевать (vagrant, homeless).

\section{COMMONLY-USED AND LIMITED ACRONYMS}

The lexicology theory shows the vocabulary can be divided into two basic types because of different ranges of application: commonly-used word and limited word. The former can be applied to many fields without limitation, the meaning of which involves in social life, economic life, cultural life and daily life, referring to the stable basic vocabulary in modern Russian vocabulary system. The latter has social geographic restrictions and the restriction of social group, divided into: dialect words, special words-professional terms, slangjargon words.

Most acronyms in Russian belong to the commonly-used words recorded in the dictionary of commonly-used acronyms. Such as: КЭДР - Конструктивно-экологическое движение России (Ecological Environment Movement in Russia), OAO - Открытое акционерное общество (Open Joint Stock
Company), ЖКД-Жидкокристаллический Дисплей (Liquid Crystal Display). The limited acronyms include:

\section{A. The Term Acronym}

The term acronym is used to name the special concept in certain field like production, scientific research and art. The basis of each term acronym must be defined by the real things represented by it, so it can concisely and correctly reflect the nature of things and phenomenon. Each discipline has the term acronym to embody the substantial contents of the term system in this discipline. Such as: the linguistic terminology ПСТ Продуктивный словообразовательный тип <лингв.> (productive word formation model), the medical termСПИД Синдром приобретённого иммунного дефицита $<$ мед.> (AIDS, the Acquired Immune Deficiency Syndrome), etc.

\section{B. The Slang Acronym}

The slang acronym refers to the open acronyms used by a certain social and occupational group connected by common interests, habits, occupation and social status. The slang acronym belongs to a special acronym in the social language. Because the slang acronym doesn't belong to the standard language, it isn't recorded in the dictionary and can only be understood by people inside the group. The followings are slang acronyms used by college students in jokes, such as the standard language (swan), the slang acronym ЛЕБЕДИ любить её буду, если даже изменит. (I still love even I am betrayed.) For another example: the standard language Ялта (Yalta), the slang acronym ЯЛТА - я люблю тебя, ангел. (I love you, angel.) Obviously, the slang acronyms not only change the meaning of original word in the standard language but also change the grammatical attribute, namely changing from nouns to sentences, decoding through jokes.

\section{THE ACRONYMS AS OBSOLETE WORDS AND NEW WORDS}

Language especially the vocabulary system of language changes with the development of society. The replacement of old things by new things inevitably leads to the continuous appearance of new words and meanings and the continuous disappearance of the old words and meanings. Therefore, all languages inevitably include positive words and negative words in any historical period.

Positive words are the core member in the language vocabulary system. It changes slowly with limited quantity, but it is used in the daily life very frequently with important communication function. These words represent the most crucial things, concepts and circumstances in the current social life, with many derived sememe, positive word formation and extensive collocational range. It mainly includes the indigenous Russian words, commonly-used words and neutral rhetorical words, as well as some foreign words, term words and professional words, literary words and words of expression.

With great changes, the negative words are in the margin of the language vocabulary system. They are vast and numerous but not commonly-used in the daily life, so the communicative function is not so important. They express 
some special and infrequent things, concepts and circumstances, or it is known by some people and used in several functional styles. The negative words include: the new words having not been commonly used; obsolete words having stopped using or used seldom.

Both positive words and negative words are not constant. The limit of them changes with the development of society and language.

New words refer to the negative words produced in the specific period, not been commonly used and still retaining the strange color. The so-called new words are a relative concept in a certain historical period. Once they are accepted by the language and listed in the positive words, they will not be new words any more. New words are produced in order to adapt to the naming of new things and new phenoma. Before and after the collapse of the Soviet Union, new things in the fields of politics, economy and culture of the society emerged in endlessly. The western science, technology and culture marched into, so a great number of new words emerged.

Obsolete words refer to the negative words having stopped using commonly, including the historical words and the outdated words. The historical words refer to the words not used commonly because the things and phenomena represented by it have disappeared in real life. They don't have synonyms retained in the positive vocabulary. The outdated words refer to the old name of real things replaced by the synonyms.

According to the lexicology theory and the semantic features of Russian acronyms, we divide the language unit into the acronym in history and new acronyms with the collapse of the Soviet Union as the break point.

\section{A. The Russian Acronyms Produced in the Soviet Union Period}

The numerous acronyms produced in the Soviet Union Period have become historical words nowadays. After the collapse of the Soviet Union, the orginal fifteen union republics became independent and the names of countries also changed greatly. For example: the mainbody of the former Soviet Union Российская Советская Федеративная Социалистическая Республика (the Russian Soviet Socialist Republic) has the abbreviated name of РСФСР, and then changed as Российская федерация (the Russian Federation) with the abbreviated name of РФ, the convenient name of Россия, becoming a totally independent political entity. For another example: the original name of the Republic of Belarus isБелорусская Советская Социалистическая Республика (БССР ), but now it is calledРеспублика Беларусь ( РБ) , namely the Republic of Byelorussia.

The research finds the national communication mechanism "Tass" ( TACC) of the former Soviet Union doesn't quit the arena of history but become ИТАР-ТАСС Информационное телеграфное агентство России Тетеграфное агентство Советского Союза (ITAR-TASS) through adding a new name to the old name. Although the Soviet Union has passed out of existence and the Советский Союз has become a historical word, its acronym still exists in the name of the biggest news agency of Russia ИТАР-ТАСС (Cheng Jiajun 2001: 89).

\section{B. New Acronyms Produced in the Recent Twenty Years}

After the collapse of the Soviet Union, dramatic changes have occurred in the fields of politics, economy, technology and cultural life of Russia. Vast new acronyms emerge in large numbers in the modern Russian. According to the research, the new Russian acronyms without changes in case and foreign acronyms occupy a large proportion.

Firstly, the name of the newly-built organizations

ГТК - Государственный таможенный комитет (Russian Federation National Customs Committee)

КЭДР - Конструктивно-экологическое движение России (Russian Ecological Environment Movement)

ШОС - Шанхайская организация сотрудничества (Shanghai Cooperation Organization)

РГБ - Российская государственная библиотека (National Library of Russia)

Secondly, the name of the new mass media organization and newspapers and periodicals

ЕАН - агентство Европейско-азиатские новости (Eurasian News Agency)

АиФ - «Аргументы и факты» (Reasons and Facts Newspaper)

Thirdly, the name of new title

CFO - Chief Financial Officer (Chief Financial Officer)

CTO - Chief technical officer (Chief Technical Officer)

Fourthly, the name of new term

ИПН - Индивидуальный подоходный налог (Individual Income Tax)

VIP-гость - Very Important Person (Very Important Person)

SARS- Severe Acute Respiratory Syndrome (Severe Acute Respiratory Syndrome)

\section{THE HOMONYM PHENOMENON PRODUCED BY THE ACRONYM}

In the vocabulary system of Russia, the grammatical form, pronounciation and writing of some words are the same but the meanings are different. These words are called the homonym. The phenomenon that the meanings of different phonetic units are different but the voice and the grammatical form of them are the same is called the homophony phenomenon.

The homonym phenomenon often happens in the acronyms, which becomes the most important factor to impede the reading comprehension. The homonym of Russian acronym appears in:

Firstly, between the Russian and foreign acronyms, like: 
БНП - боевой наблюдательный пункт (Combat Observation Post)

БНП - BNP, Banque National de Paris (Banque National de Paris)

Secondly, between foreign acronyms, like:

VCR - Video Cassette Recorder (Video Cassette Recorder, now it often refers to a video clip)

VCR - Variable Compression Ratio (Variable Compression Ratio) like:

Thirdly, between the commonly-used and term acronyms,

БНС - бюро несчастных случаев (Accident Department)

БНС - батарея накала сухая (<wireless $>$ filament dry battery)

Fourthly, between the new acronym and the original Russian acronym, like:

BBS)

РИФ - Российский Интернет-Форум (Russian Internet

РИФ - редакционно-издательский факультет (Editing and Publishing Department)

Fifthly, between new acronym and notional word, like:

Mapc (Mars)

MAPC - Машина Автоматической Регистрации и Сигнализации（Automatical Recording Signal Machine ).

\section{CONCLUSION}

The research finds: all new Russian acronyms are monosemes. The synonymy exists between new acronyms and the primary structure. Numerous foreign acronyms derived from English are widely applied to social fields. According to the range of application, the new Russian acronyms can be divided into the commonly-used acronyms and the limited acronyms. According to the appearance and existence of words in the language, the Russian acronyms can be divided into the obsolete words and new words. The homonym phenomenon among acronyms is ubiquitous.

\section{REFERENCES}

[1] Cheng Jiajun. Modern Russian and Modern Russian Culture [M], Shanghai: Shanghai Foreign Language Education Press, 2001

[2] Wang Yangzheng. Social Change and the Change of Russian Language [M], Harbin: Heilongjiang People's Publishing House, 2008

[3] Yang Jie. A Survey of Russian Lexicology [M], Shanghai: Shanghai Foreign Language Education Press, 2009

[4] Zhang Jiahua. The General Theory of Russia in the New Era [M], Beijing: The Commercial Press, 2006 